$\left.50 / 0^{5}\right)^{3} n^{3+1} \quad$ on- 1458 LA-5986-MS, Vol. I

Informal Report

Optical Design of a Reaction Chamber for Weakly Absorbed Light

I. Canted and Parallel Mirrors

by

J. J. Devaney

D. E. Jackson
UC-20 and UC-34

Reporting Date: May 1975

Issued: June 1975

\title{
os Lalamos
}

scientific laboratory

of the University of Californio

LOS ALAMOS, NEW MEXICO 87544

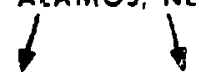

An Alfirmative Aclion/Equal Opportunity Employer 
In the interest of prompt distribution, this report was not edited by the Technical Information staff.

Printed in the United States of America. Available from National Technical Information Service

U S Department of Commerce

5285 Port Royal Road

Springtiold, VA 22151

Price: Printed Copy 14.00 Microfiche \$2.25

This report wal prepared at an account of work oponsored

br the Linited Stoles Government. Neither the United States.

nor the United Stetes Fnerty Reserch and Development Ad.
minimtration, nor eny of thetr employees, nor any of their con-

iractors. unbcontractors, or their employees. makes any

respontibility for the accuracy, completeness, or usefolity of

ans information. apperatus, produet, or process ditucloess, or

reprearnte that its une would nat infrince privately owned
rixhly. 
This report was prepared as an account of work sponsored by the United States Government. Neither the United States nor the United States Energy Research and Development Administration, nor any of their employees, nor any of their contractors, subcontractors, or their employees, makes any warranty, express or implied, or assumes any legal liability or responsibility for the accuracy, completeness or usefulness of any information, apparatus, product or process disclosed, or sepresents that its use would not infringe privately owned rights.

OPTICAL DESIGN OF A KEACTION CHAMBER FOR WEAKLY ABSORBED LIGHT

I. CANTED AND PARALLEL MIRRORS

(With an Appendix for Strongly Absorbed Light Waves)

by

J. J. Devaney and D. E. Jackson

ABSTRACT

The optimization of light absorption in a weakly absorbing medium is studied by repeatedly reflecting a light beam from elther plane or cylindrical canted and parallel mirrors. Vertical control is exerted either by horizontal mirror reflection, by cylindrical end mirrors, or by wellcollimated or focused beams. Useful absorftion for a number of numertcal parameiers is calculated. The gross propertles of lasers are characterized for geonetrical optical purposes. Beam insertion optics are evaluated. Chamber and mirror energetics are considered. In the Appendix one of us (JJD) gives the shape and speed of a light beam eating its way into a very highly absorbing medium.

\section{INTRODUCTION}

This report, the first of a series, deals with the optimum illumination of a reaction chamber by weakly absorbed 1 ight which, as a specific example, we take to be $20.4-\mu$ m wavelength. Only plane (or sylindrical) mirrors without external beam return are constdered in this report.

Our reaction chamber or active region has width $w$, length $L$, and height $h$, across which (In the wdirection) we pass a light beam of helght $h$, reflecting it from mirrors at the $h \times l$ faces in Fig. 1 . We suppose as a nominal, but high-quality value, a beam loss per pass of $0.5 \%$ for mirror loss and use-. less gas absorption, a number which we will subsequently vary.

For the moment we study a single beam in plane or nearly plane mirror geometry. We call for heams of uniform intensity or nearly so; the examination of significantly nonuniform initlal beams is reserved for later studies. It is, of course, evident that uniform beams lead to ease in rendering uniform illumination of the reaction chamber.

We w11l later $f$ ix many extraneous parameters so that we can concentrate on the effects of varying

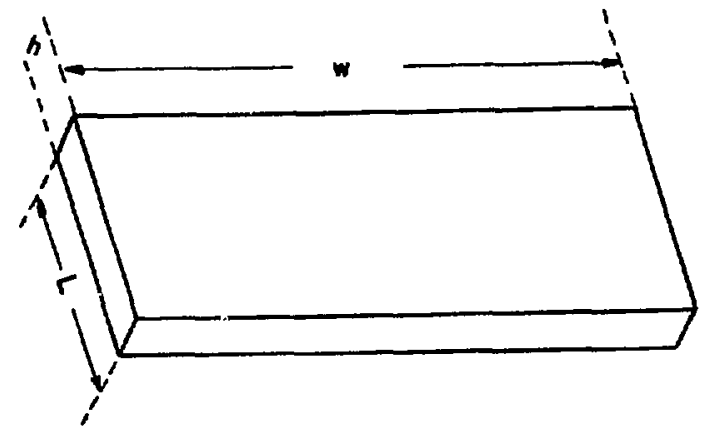

Fig. 1. Reactiun chamber.

just the optical beam parameters to determine beam smoothness, efficiency, intensity, and time.

Because our light is only weakly absorbed in the cavity medium, efficlent use of the light beam requires many passes through the reaction chamber. Beam losses due to divergence and diffraction must therefore be carefully controlled. 
The order of top1cs 1s: II. Vertical containment, III. Horlzontal Containment, IV. Laser Characterization, V. Beam Insertion Optics, VI. Numerical Examples, VII. Chamber Energerics - Mirror Intensities, and Appendix, High Absorption of Light, Bleaching.

\section{VERT ICAL CONTA INMENT}

We wlll discuss vertical containment by: (a) horizontal mirrors; (b) a well-collimated beam; and (c) cylindrical end mirrors.

\section{A. Horizontal Mirrors}

If the chamber could be fitted with reflecting surfaces above and below, then from Born and Wolf, 1 for a grazing angle $\delta$, from a medium of refractive Index 1 to a metal of real index $n$ and Imaginary part $n k$, the second-order (in $\delta$ ) approximation to reflectivity $R$ is given by:

$$
R_{\mathrm{TE}}=\frac{\left(\delta-\mathrm{u}_{2}\right)^{2}+\mathrm{v}_{2}{ }^{2}}{\left(\delta+\mathrm{u}_{2}\right)^{2}+\mathrm{v}_{2}{ }^{2}}
$$

(electric vector perpendicular to plane of incidence) and

$R_{T M}=\frac{\left[n^{2}\left(1-\kappa^{2}\right) \delta-u_{2}\right]^{2}+\left[2 n^{2} k \delta-v_{2}\right]^{2}}{\left[n^{2}\left(1-k^{2}\right) \delta+u_{2}\right]^{2}+\left[2 n^{2} k \delta+v_{2}\right]^{2}}$

(magnetic vector perpendicular to plane of incidence) where $U_{2}$ and $v_{2}$ are to be obtained from:

$$
\mathrm{U}_{2}^{2}-\mathrm{v}_{2}^{2}=\mathrm{n}^{2}-\mathrm{n}^{2} \mathrm{k}^{2}-1
$$

and

$$
u_{2} v_{2}=n^{2} k \text {. }
$$

Taking values of $n$ and $n K$ from the APS Handbook, $"$ we obtain the reflectivities sumarized in Table I.

Clearly our reflection losses will be large unless grazing angles are very small or highly reflecting surfaces are used. Note that TE reflectivity is greatly superior to TM.
TABLE I

GRAZING REFLECTIVITIES

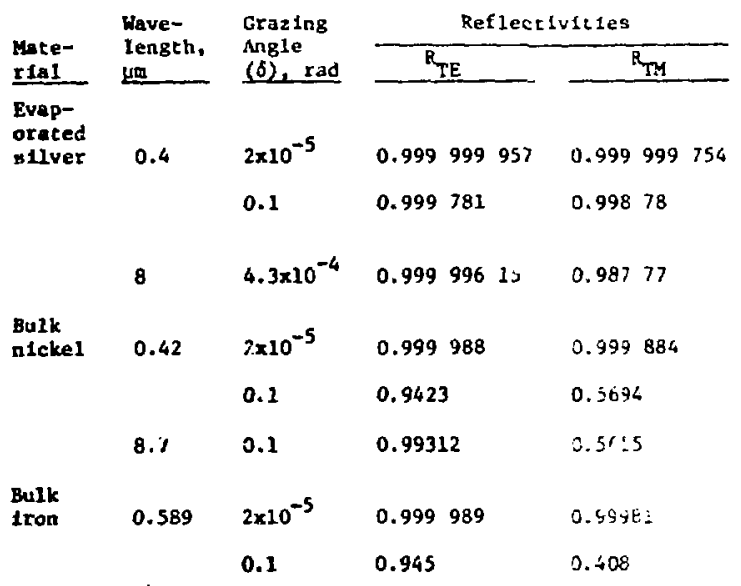

\section{B. Collimated Beam}

Should other considerations preclude use of horizontal mirrors, we can control beam loss by controlling the beam quality. A beam with a divergence of the order of 0.1 -rad half-angle w111 10se $\approx 95 \%$ of its intensity in a single $200-\mathrm{cm}$ pass. However, a diffraction-limited beam of $\sim 0.4-\mu \mathrm{m}$ wavelength wich a minimum vertical dimension of $1 \mathrm{~cm}$ (called the walst) expands by a factor of $\sqrt{2}$ in a discance (called the Rayleigh range) of $20000 \mathrm{~cm}$. By taking twice the Rayleigh range as the length of the usefully controlled beam, we could get 200 passes of $200 \mathrm{~cm}$ each in which the beam changes from a helght of $1.41 \mathrm{~cm}$ to $1 \mathrm{~cm}$ (walst) and back to $1.41 \mathrm{~cm}$. Simllarly, the Rayleigh range of a $2-\mathrm{cm}$ vertical opening $1 \mathrm{~s} 80000 \mathrm{~cm}$ or 800 passes $(200 \mathrm{~cm})$. The corresponding values for a collirated $8,6-\mu \mathrm{m}$ beam of $1-\mathrm{cm}$ walst are $911 \mathrm{~cm}-9$ passes; and for a 2-cm walst, $3644 \mathrm{~cm}-36$ passes. Thus vertical optics are easier for a 2-cm-high reaction chamber than for a $1-\mathrm{cm}$ chamber (see also discussion of cylindrical mirrors, below).

To hold a $1-\mathrm{cm}$ vertical beam for the order of 100 passes withuit cylindrical optical elements, the beam wust be formable into a diffractionifmited beam. In contrast, as discussed below 
(Sec. III), we can tolerate a much greater horfzontal divergence if need be. Vertical tradeoffs are as follows: For a focused beam with a $1-\mathrm{cm}$ waist and for 200 passes of $200-\mathrm{cm}$ length (with no loss), the diffraction-limited variation of the $90 \%$ beam limlt is 1.41 to 1 to $1.41 \mathrm{~cm}$ giving an effective illumination within $1 \mathrm{~cm}$ of $83 \%$. For $90 \mathrm{no-loss}$ passes the beam changes from 1.096 to 1 to $1.096 \mathrm{~cm}$ giving an effective 1-cm illumination of $95.4 \%$. Average diffraction losses are summarized in Table I1. Note that these losses are initial losses of a unfiform beam in one dimension. Repeated passes lead to Gaussian shapes, with eventually vanishingly small diffraction losses, espectally for concave mirrors; e.g., for confecal, 1-cm-h1gh by 200-cmradius TEM ${ }_{00}$, the diffraction loss is less than $0.001 \%$ per pass. ${ }^{3}$

TABLE II

AVERAGE ONE-DIMENSIONAL INITIAL DIFFRACTION LOSSES

(200-cm pach length, uniform beam)

$\begin{array}{lllll}\text { Vertlcal aperture, (cm) } & 1 & 1.41 & 2 & 4 \\ \text { Relative loss, (\%) } & 0.16 & 0.08 & 0.04 & 0.01\end{array}$

If beam divergence is $2 x$ diffraction limited (DL) the effective illumination drops to $61.8 \%$ for 200 passes $(200 \mathrm{~cm}$ ) and to $85.3 \%$ for 90 passes. For a $3 x$ DL the no-loss beam is $48 \%$ effective for 200 passes and $74.7 \%$ for 90 passes. For $5 \times$ DL the effectiveness of 200 passes has dropped to $32.8 \%$, whereas for $10 \mathrm{x}$ DL and 90 passes the effectiveness is $35.7 \%$. Note that wider divergence 1mplies a need for larger end mirrors; for example, a $2 x$ diffraction-limited beam requires a mirror depth of $1.35 \mathrm{~cm}$ to reflect the same proportion of beam at 90 passes and requires $2.24 \mathrm{~cm}$ at 200 passes. A 3x diffraction-1imited beam requires $1.69 \mathrm{~cm}$ for 90 passes and $3.16 \mathrm{~cm}$ for 200 passes. To a first approximation the early, average diffraction loss may be taken as a function of mirror depth only as given in Table II (e.g., 1-cm mirror, $0.16 \% /$ pass).

\section{Cylindrical End Mirrors}

As mentioned, we can improve beam effectiveness by using a deeper reaction chamber, by fewer passes, or by going to a cylindrical mirror for one end (only one end is needed). However, the last method may reduce beam effectiveness due to a loss of uniformity which is espectally serious close to absorption saturation.

The cylindrical and the plane mirror together form a stable resonator, which we should design for nearly uniform volute lllumination. By using one cylindrical mirror of $20-\mathrm{km}$ radius, we may increase the effectiveness of a diffraction-limited beam to 0.999975 , or a $2 \mathrm{x}$ DL beam to 0.999 , and of a $10 \mathrm{x}$ DL beam to 0.9975 ; that is, make the beam essentially $100 \%$ effective because it is effectively $100 \%$ paraxtal.

Starting at the curved cylindrical mirror with a focal length $f_{m}=R / 2$ and traversing the chamber twice, beyond the plane mirror and to just beyond the curved mirror again, the ray transfer matrix for 2n passes is from Sylvester's theorem and some algebra: ${ }^{3}$

$M^{n} \approx \theta^{-1}\left[\begin{array}{ll}\theta \cos \left(\frac{2 n-1}{2} \theta\right) & 2 w \sin n \theta \\ -\frac{1}{f_{m}} \sin n \theta & \theta \cos \left(\frac{2 n-1}{2} \theta\right)-\theta^{2} \sin \theta \theta\end{array}\right]$

for

$$
\theta \equiv \sqrt{2 w / \epsilon_{m}} \ll l,
$$

so that a ray starting at $x_{0}$ with slope $x_{0}^{\prime}$ has

$$
\begin{gathered}
x_{2 n}=x_{0} \cos \left(\frac{2 n-1}{2} \theta\right)+2 w x_{0}^{\prime} \sin n \theta / \theta \text { and } \\
x_{2 n}^{\prime}=-x_{0} \sin n \theta / f_{m} \theta \\
+x_{0}^{\prime} \cos \frac{2 n-1}{2} \theta-\theta x_{0}^{\prime} \sin n \theta
\end{gathered}
$$

from 


$$
\left[\begin{array}{l}
x_{2 n} \\
x_{2 n}^{\prime}
\end{array}\right]=M^{n}\left[\begin{array}{l}
x_{0} \\
x_{0}^{\prime}
\end{array}\right] .
$$

Equation (5) shows that provided the initial slope $x_{0}^{\prime}$ is not too large, the ray is confined. Which is, of course, to say that the system is a stable resonator vertically, as expected. Indeed, for small $\mathrm{x}_{0}^{\prime}, \mathrm{x}_{2 \mathrm{n}} \lesssim \mathrm{x}_{0}$.

Cylindrical mirrors of shorter radii allow us to handle very poor beams, which we will discuss by changing the beat characterization from a multiple of the diffraction-limited divergence to an effective source si<e $s$, and a useful half-angle $\phi$, for the entrance lens with a focal length $f$. Let the entrance-window aperture be $a$, we have a single curved mirror of radius $R$, focal length $f_{m}=R / 2$, and depth $a$, and a flat mirror of depth $b$, spaced $L=200 \mathrm{~cm}$ apart (see Fig. 2).

In Fig. 2, for optimum illumination the source must be imaged on the first mirror (flat) of size equal to the depth, $h$, of the reaction chamber, thus the entrance lens must magnify by an amount $m$, given by:

$$
h=-m s \text {. }
$$

The fmage distance $Z$ and object distance $Z^{\prime}$ are also irelated to $m$ through:

$$
2^{\prime}=-\mathrm{m} 2
$$

and to $f$ by:

$$
\frac{1}{z}+\frac{1}{z^{\prime}}=\frac{1}{i}
$$

so that setting $z^{*}=1$ we have

$$
f=-\frac{L S}{S} \frac{T}{h} \text {. }
$$

giving the focal length of the entrance leas with the source located at

$$
z=\frac{S L}{h} \text {. }
$$

The maximum vertical source angle at which 11 ghe is accepted into the system is $\$$, given by:

$$
\tan \phi=\frac{a}{22}=\frac{a h}{2 S L} \text {. }
$$

Rays at any greater angle are lost. Within the chamber we refocus to $h$ so we must put

$$
\frac{L}{2}=\mathbf{f}_{\mathrm{m}}=\frac{R}{2}
$$

or

$$
\mathbf{R}=\mathrm{L},
$$

where $R$ is the radius of curvature of the cylindrical mirror. If the source obeys lambert's Law in

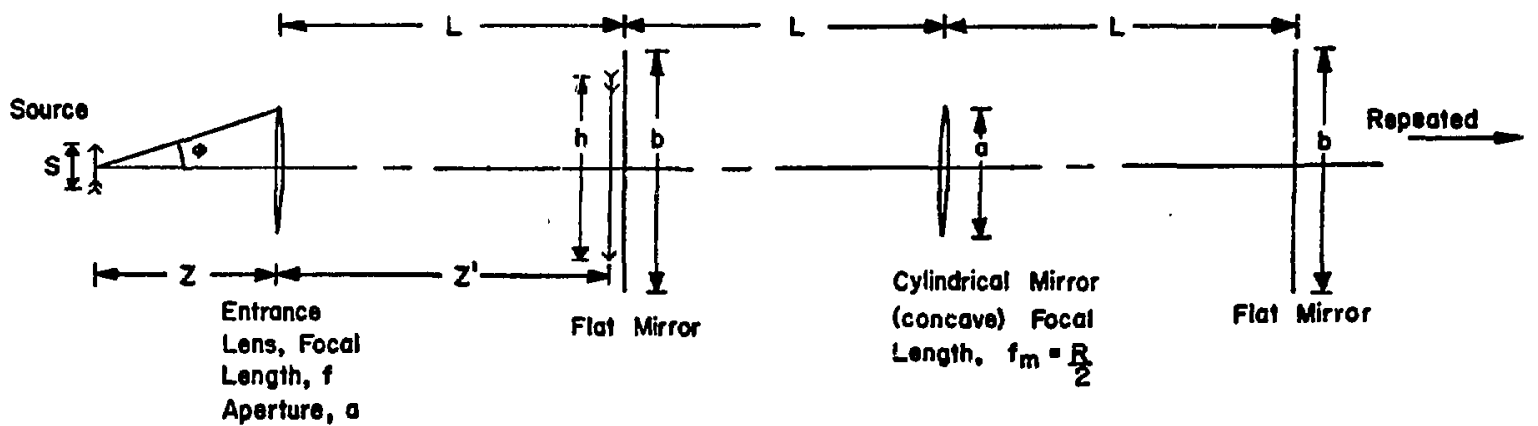

Fig. 2. Vertical optics - cylindrical mirror (expanded). 
object space, the image does in image space, and we can therefore calculate the effectiveness of illumination of the reaction chanber for large angles, $t$. We exhibit the result for $2 \mathrm{~h} \geq \mathrm{a}=\mathrm{h}, \mathrm{L} \gg \mathrm{h}$ to wit: the incfective fraction is;

$$
F=\frac{a-h}{4 h} \text {, }
$$

and for $L, a \leq 2 h$;

$$
F=1-\frac{h}{a-h}\left(\frac{3}{4}+\frac{1}{2} \ln \left|\frac{a-h}{h}\right|\right) .
$$

Viute however, that for a given source a larger aperture a diwys increases the absolute effective illumination up to saturation in the gas, even though the relative effectiveness decteases with a. Equatious (13) and (14) give the fractional ineffectiveness of wide-angle light because the light is outside the reacting volume. In all of the above. the averabe early difiractive losses are roughly those of Table 11, and thus depend primarily on a and $b$. As the beam progresses, loss becomes negl1gitile as uniformity degenerates to a Gaussian shape.

\section{1). Insertion Lens Control}

If unfortity ls not essential we can use a more converging leas than given by $E q .(9)$ and thereby somerol vertical divergence, or use plane mirrors plus a different lens than that given in Eq. (9). We will discuss the matter after we introduce larea characterization below.

111. HOR1\%UNTAL CONTAINMENT

Wi: now turn to lllumination in the horizontal dimensluns where we will "walk" the beam Jown and up (in the 1. dimension) from a single entrance window thus tlluminat ing the whole volume. Both to avoid hot spots on the mirrors and for optimum reactivity In all the madium, it is best to stare wh a beam of uniform incensity and examine the effects of diffraction (from the entrance aperture), transmitting losses, time, and chamber geometry. This we do below, leaving the spectal effects of sharply nonuniform beams for a later study.

By making many passes through the medium volume we utllize the 1 ight., with its weak absorption, most effectively. In general and until diffraction

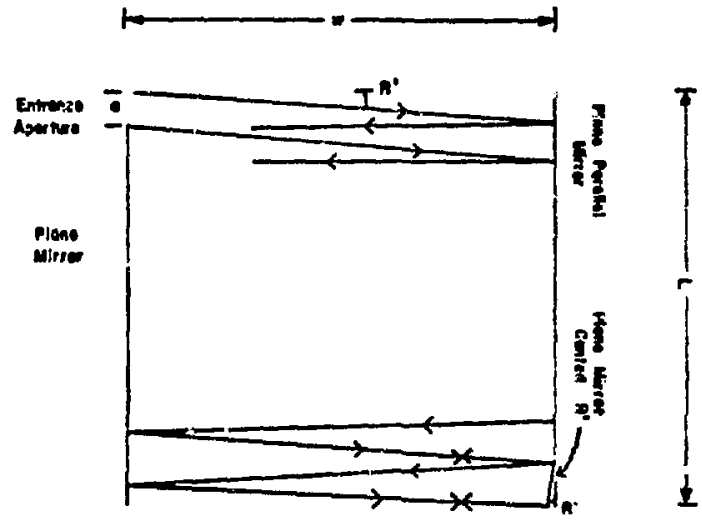

Fig. 3. Horizontal reaction chamber, Version a, parallel end mirrors. Beam-reversal mirror canted at angle $R^{\prime}$ width a (strictly speaking should be width of walst of beam which started at a).

broadens the beam excessively one does better in number of passes, in total absorption, and in intensity multiplicarion with narrow beams $(20.25 \mathrm{~cm}$ for $w=200 \mathrm{~cm}$ ) at the cost of some l1lumination uniformity which may efther pose an intensitytolerance limit on mifrors and/or cause the loss of effective 1llumination at the corresponding lowlevel portions of the chamber.

We propose two designs. The first, Type a (F1g. 3), using plane parallel wirrors (the term plane refers to the horizontal dimension; the vertical options have been discussed in 12 ), plus a plane reversing mirror has the metit of controlling the aver:"e uniformity in the chamber to a few percent. The second, Type b (FIs. 4), using slightly canted

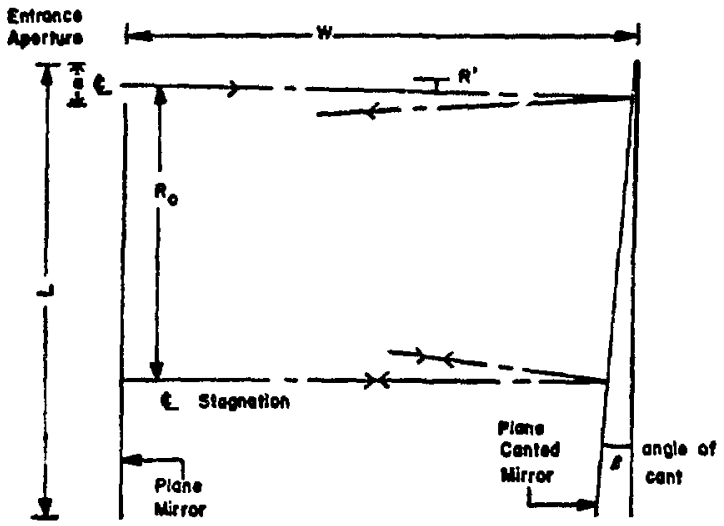

Fig. 4. Horizontal reaction chamber, version b, canted end mirrors. 
plane mirrors can achleve more than twlce the bes: Type-a absorption, but of course through trapping the bean for a hlgher nurber ut passes for a longer tite and permitcting greater intensity variations.

\section{A. Parallel End Mirrors. Trpe a}

This destgn depends on obtaining a well-col1 imated beam in the sense that divergence may be neglected whllo the beam is in the cavity. The ingle $R^{\prime}$ is given by tan $R^{\prime}=a / 2 W$. For an entrance apercure of $a=1 \mathrm{~cm}$, the number of passes before loss at the top is 39 in a $200: 10 \mathrm{~m}^{2}$ chamber, with an optimum beam-width variation of 1.037-1.0$1.037 \mathrm{~cm}$ and a useful beam absorption of $2.58 \%$ with an average unfformity of $\pm 0.3 \%$ over $1-c m$ increments in the dowstream direction except for the entrance where the total intensity is $20 \%$ lower. For $a=1 \mathrm{~cm}$, $R^{\prime}: 0.0025$ rad.

Stretching this concept of nondivergence a lftcle, the values for an entrance aperture of $a=0.5 \mathrm{cs}$ are: number of passes, 79; opt lmusm beamwidth varlation, 0.75-0.50-0.93 cal (hardly nondfvergent); but a good useful absorpticn of 4.68\% with an average uniformity of $\pm 1 \%$ except for the entrance increment where the integrated Intensity is $10 \%$ lower. For $a=0.5 \mathrm{~cm}, R^{\prime}=0.00125 \mathrm{rad}$.

These examples demonstrate some pros and cons of thlo version. We wlll give integrated intensities relative to entrance bead intensities and power together with those of Type b in Sec. VI.

\section{Canced End Mirrors, Type b}

Consider the horizontal geometry of Fig. 4 . The two end mirtors are canted so that a beam introduced at the upper left, aperture $a$, will reflect back so as to just miss its entrance aperture and w111 continue reflecting down the reaction chamber but at ever decreasing intervals of $L$ between reflectlons until it ceases to progress downstream, reversing at the stagnation line tu progress upward with greater and greatie intervals untll it is 1 ist at the top of the reaction chamber. Such an optical geometry has a very simple representation by forming the successive Image spaces as in Fig. 5. Let the initial (uniform) beam be of width $a$ and angular divergence, $\theta$, so that $t$ ts one-dimensional crosssection at a distance, 2 , from the aperture is

$$
C: a+22 \tan \theta \text {. }
$$

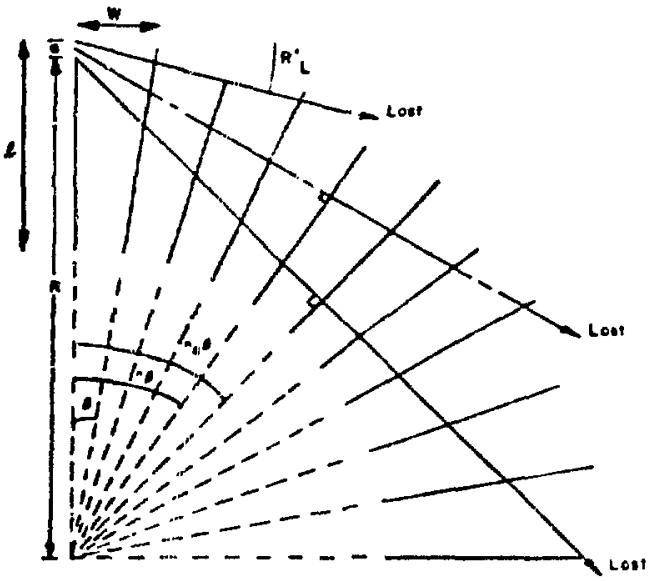

Fig. 5. Equivalent (to Fig. 4) perlodic op: ibil system (not to scale).

For diffraction-limited beems in one dimention $\therefore=1 / a$ and in the far fleld (2. a a c Incluctes

89.1\% of the beam. For simpliclty we will take c to include (tniformly) all of the bean. The subscript L therefore refers to the left or upper cdge of such a beats traveling right, no subscript to the center, and the subsertpe $A$ to the right. The sadius $k$ is determined by trigonomentry to be

$$
R=w / t a t ;
$$

and the anple $R_{i}^{\prime}$ is determined so thot the left beam edge just elears the entrance window after the crst reflection:

$\cos \left(R_{L}^{\prime}-2 a\right)=\left(1+\frac{a \tan G}{\omega}\right) \cos R_{i}$.

$R_{L}^{\prime}+\theta=R^{\prime}: R^{\prime}+\theta=R_{R}^{\prime} ; R_{L}^{\prime}+2 \theta=R_{R^{\prime}}^{\prime}$

Fo: a given ray, stagnation occurs when that ray is perpendicular to a mirror, say the $n^{\text {th }}$ mirror trage at an angle $n B$. Let the distance the ray has traveled to stagnation be $I_{S}$, then:

$$
L_{s}=\frac{w \sin n g}{\tan B}=\frac{w \sin R^{\prime}}{\tan B}
$$

where $n$ is the number of passes to stagnation given by : 


$$
n=R^{\prime} /:^{*} \cdot
$$

The distance downstream to stagnation is:

$$
v=W\left(1-\frac{\left.\cos R^{\prime}\right)}{t a n}\right.
$$

The number of pasties, $n_{i}$, unt il the left or upper edge of the beatm just loaks out the top is given by:

$$
n_{l}^{\prime}=2\left(\frac{R_{L}^{\prime}}{!}-1\right)
$$

The number of passes, $n$, for the team center to return to the entrance center is:

$$
n^{\prime}=2 K^{\prime} \%
$$

and the corresponding cotal path to escape of the bealm centcre is:

$$
L_{\operatorname{lotal} 1}=\left(a+2 \frac{W}{\tan B}\right) \sin K^{*} .
$$

Equactons (15) to (24) permit calculation of the geometrical excursions of a beam of width a and divergence ". For example, for a $200 \times 10 \mathrm{~cm}^{2}$ chamber and for a $0.5 \mathrm{ca}, \lambda \sim 0.4 \times 10^{-4} \mathrm{~cm}$ and a divergence of $2 x$ diffraction imited, we find that the mitrors must be canted at $B=2.66 \times 10^{-5} \mathrm{rad}$, out of parallel, and that the beam aust be shot in at an angle of 0.00143 rad in order that the right beam edge will stagnate exactly at the far (bot:om) edge of the mirrors in Fig. 4, giving 60 passes to stagnation and $n^{\prime}$ a 108 passes to entral leakage at

top. But more relevant paraneters are the cotal useful absorption and the uniformity thereof, which we consider next.

A program, Absorption D1stribution, has been written and tested for the HP-9820A computer, wh1ch does some of the preceding trigonometry, plus intensicy calculations; namely it keeps track of the beam center and width, determines $R^{\prime}$ and $\beta$, and gives the total absorption as well as the relative absorption per cell. A cell is defined as $1 / 20 \mathrm{th}$ of the downstream reaction chamber times the full width and depth. At the center of the chamber width the program adds the faction of each beam in the cell times its intensity to give the total intensity in the celi. The inputs are (FIg. 4):

1. Beam entrance diameter, a;

2. Distance of beam center to stagnation, $R_{0}$;

3. Downstream length of chamber, $\mathrm{L}$;

4. Crose-stream width of chamber, $w$;

5. Beam divergence, half-angle, 6 ;

6. REFL, reflectlvicy of mirrors less any other losses, $R$;

7. TRANS, transmissivity of the gas, $T=1$ - useful absorption = 1 - wod; and

8. REPORT, the number of passes (plus one) at which the ubsorption and its distribution are desired; these are always given for the maximum number of passes also.

As above, the program requires the diverging beam to just miss the entrance aperture af $t \in r$ the first reflection. It then calculates $R^{\prime}$ and $B$ to sat1sfy stagnation of the center at $R_{0}$, and thus can calculate the entire trajectory of the beam.

lyaving these parameters describing the position and width of the beam, absorption for a particular pass is calculated as follows.

1. Calculate any energy that may be lost out of the chamber at elther end.

2. Ca!culate how much of the remaining energy is absorbed by using the transmissivity of the gas.

3. Calculate the energy absorbed in each cell as proportional to the area common to the beam and that cell.

Energy loss to the wall 19 chen calculated from wall reflectivity, followed by calculations of the new beam position and width, and so on until the tralling edge of the beam leaves the chamber.

The program prints $\theta, T, R, a, R_{0}, L, w, B / 2$ (called ALPHA), and $R^{\prime}$. It llats the center of the entrance window and gives the beam center and edges as well as the beam energy before the pass and the absorption of the last pass at the beginning of the third pass and at every tenth pass, or for every pass if desired. It gives the total absorption as a fraction of the input beam intensity and the percent of that absorption in each of the twenty cells; all being given both at the beginning of the REPORT 
designated number of passes ant at the end of the total possible passes. It lists that total and gives the curning-point location plus a check on the sim of cellular absorption. The parameter study below was made with the foregolng program.

\section{LASER CHARACTERIZATION}

For estimating the cavicy performance of beams far from diffraction 1 inlted, we need a description of the gross features of a laser adequate to give the device in sufficient detall to enable us to compute the photometry of optical systems in both the near and far flelds of the various image spaces and to at least a useful approximation. The purpose here is to characterize a partially incoherent laser beam well enough to determine reaction chamber properties leaving the fine details for more soptisticated (and time consuming) theory such as that of Fox and Li, ${ }^{4}$ of Terrell, ${ }^{5}$ or of Suydam, ${ }^{6}$ all based on Huygen's principle. Laser beams that are nearly diffraction 1 imfted should be treated by the well known coherent Gaussian-mode beam optics.

We suggest then that a laser be characterized by a convex lens of aperture $2 c$ equal to the effective exit window of the lasci together with a flat plate disk light source of diameter $2 b$ located at the focal point, $f$, of lens $c$ (see Fig. 6). The brightness of source $b$ is a function of position on the $d i s k b$, and for that mater the transmission of the lens $c$ can also be made a function of position. Such a laser model, or its image space equivalent below, is easily propagated through an optical system by successive imaging. Moreover the characterization fits the gross features of lasers, the limfting features of lasers, and varies smoothly and plausibly between limiting features, For example,

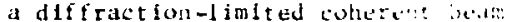

seting b equal to zero, the the

In the rea! laser, beln.: sive't by t.a

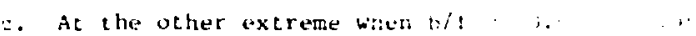

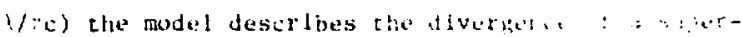
radlant or near super-radtant laser, t. . . .... . . :

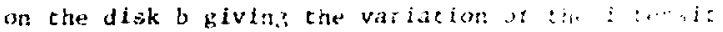
witt: angle.

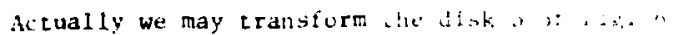
Into the Image space of the leas equavalent characterizat lon ai fig. $7.4 . .4$ is the thage space tratsform of the disk !; . . : ise exit pupil of the system and determines the $1:$ : rattive spread of the laser beam. The truantidit: wh miy as before be varted across c. $e$ is a la: plate light source with the ratic eid, giving for latrinsic nondiffractive spread of the later buth. ist

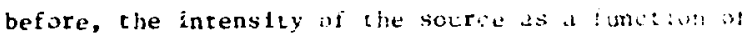
angle is given by the (photometric) bitintisess function over the disk whose radius is a.

As an example we work a first approximition that certainly does not exhaust the details of the model much less the complexity of a real beam. We thus describe a beam for which we have only two experimental numbers, nameiy the laser exit bedm diameter of $0.5 \mathrm{~cm}$ and a distant angular spread of $1.3 \mathrm{mrad}$. These values decermine $c=0.25 \mathrm{~cm}$ and $\mathrm{e} / \mathrm{d}_{0}=1.3 \times 10^{-3}$ radlans, and we put $\mathrm{d}_{0}$ at the approprlate distance to give the proper diffaction, to wit, $c / d_{0}=1 /$ ilc for a cuherent ioussiar beam whence for say, $A_{i} 0.4 \mathrm{~km}$ and $d_{0}=5020 \mathrm{~cm} \mathrm{we} \mathrm{ob-}$ talne $=6.5 \mathrm{~cm}$. We now ran lmage e through our system by geometrtial optics and obtain thereby a f:rst, and for most photonetric purposes, a more than adequate analys is.

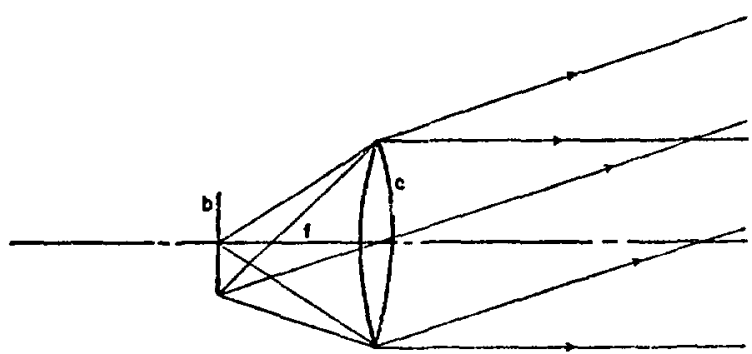

F1g. 6. Laser characterization.

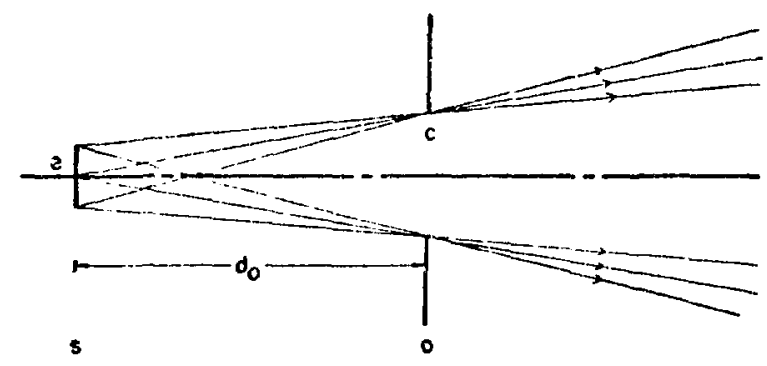

Fig. 7. Equivalent laser characterization. 
Apatin we would caut ion the reader that our characterlaation and arialaly the above oversimplified model is not fateraded to be all things to all fousole. Kather he submat the mudel ab a way to use a pauc lity of experdantal dals to make first-order calculations that must be cartefily examined at each suecedlag step to mike sure that the model does not wersimplify physical reality. With these caveats, the nodel proves highly userul.

v. MEAM INSHRTION OPTICS

In adtit ton to the paraferers of the chamber

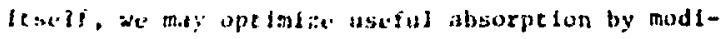
fying the lisere bean thefors insereton. he consider

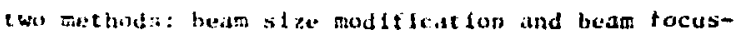
ing. In bot thece are tradeofis. Compressing the beam (fwrizontally ln one dimeaston) is advantageous, but concomflarely the bean diverges, whth is disadrantageous. Focusing allows the beam to return from the flest refiection as a smaller angle and still thiss the etitrance hale thus packing mote passes tonea the chamber, but conerarlly the beam may diverge greater further on; or focusing may be used just co control difiracelon sufficienty for the fall berm stavel to be accomplfsiced. In all these vartaztons, mirror damage thresholds and the effects on illumlnation unlformlty must be kept in mind.

\section{A. Bean Conpression (Expansion)}

bug for "roos" heans and for diffraction-

limited beams, compression of the beam diameter by a factor $m$ expands tie beam divergence by a factor $1 / \mathrm{m}$. He lllusirate this effect by the action of a Galilean telesiomt on a laser beam as cha"acerized in Fig. 7 (sev $\mathrm{Fig}$. 8). The celescope is made up of a convex lens. $f_{f}$, and a roncave lens, $f_{4}$, obeving $f_{3}+f_{4}=d$, and compresing the beam by a factor $m=-f_{4} / f_{3}$, simuleaneously expanding the beam divergence from $n$ to $/ \mathrm{m}$, as we wlll show. The transfer matrix taking a ray from the source $e$ to

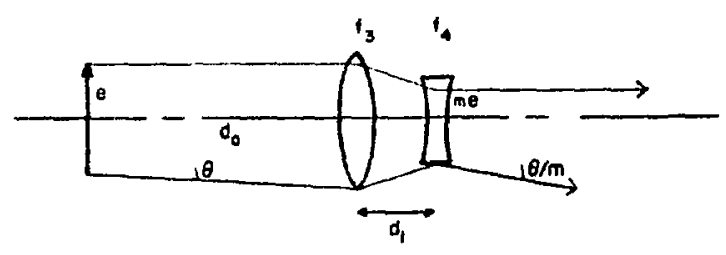

F1g. 8. Beam compression by Galllean telescope.
Just beyond the leas $\mathrm{f}_{4}$ fs:

$$
M=\left[\begin{array}{ll}
\pi & d_{i}+d_{0} m \\
0 & 1 / 0
\end{array}\right] .
$$

The bean edge ray at the source, $e$, has position and divergence half angle or slope $\theta$, so that the posicion vector at $f_{4}$, call it $x_{0}$, 19 given by:

$x_{0}=M x_{c}=M\left[\begin{array}{l}e \\ y\end{array}\right]=\left[\begin{array}{l}m e+\left(d_{1}+d_{0} m\right) \theta \\ s / m\end{array}\right]=\left[\begin{array}{l}x_{0} \\ x_{0}^{\prime}\end{array}\right]$.

We can make $d_{0}$ and $d_{1}$ as smali as we please; ${ }_{0}$ me is just the bean spread through the telescope, and $a_{1}$ is the bean spread from the laser to the telescope. Thus the effect of the telescupe, as asserted, is to compress the bean by a factor and enlarge the divergence oy a factor $1 / \mathrm{m}$.

We now lmagine the beam from lens $f_{4}$ to be introduced Into the reaction chamber or into an Insertion sens of the reaction chamber. What are the spparent size $e_{0}$ and distance $d_{b o}$ of the source viewed srom the reaction chamber? If we make $\theta$ $=e / d_{0}$ In Er. (2.6) then clear:y $e_{0} / d_{00}=(1 / m) e / d_{0}$. Using

$$
e_{0}=m e
$$

we have

$$
d_{00}=m^{2} 0_{0}
$$

thus giving the apparent source size $e_{0}$ and distance $i_{\text {oo }}$ if a telescope of magnification $m$ is inserted in the bean.

\section{B. Insertion Optics}

Down beam from the telescope for combined into lens $f_{4}$ ) we may want to insert a converging lens at the chamber entrance (usually). What performance can we expect? Consider Fig. 9. Our laser beam emanates from a a distance $d_{0}$ from the insertion lens of diameter $2 c$ and focal length $f$, which focuses 


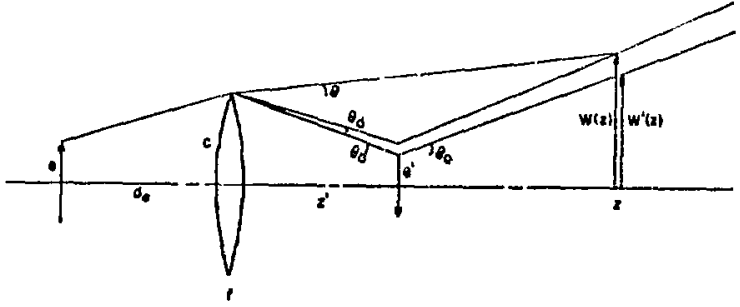

Fig. 9. Insertion lens - effective beam spread.

the bear to a slope $\theta_{0}$ at ' 2 ' with image $e '$. The term $\theta_{d}$ denotes the effective diffraction angle from the aperture $2 \mathrm{c}$; for a unform one-dimensional beam its value is $\theta_{d}=\lambda / 2 c, w(z)$ is the net width and $\theta$ the net divergence from $c$ of the beam at distance $Z$ from c. Usually we will want to minimize $w$ and henee $\theta$ for a total path $Z$ through the chamber. Also a slighcly closer beam return to the entrance may glve slightly better total absorption even though the beam escape losses are greater for larger w at larger $Z$ where the attenuated beam contributes little absorption, a refinement we do not consider at this time. We def Ine w' by

$$
w^{\prime} \equiv w-2 \theta_{d}
$$

Minimizing $w^{\prime}$ minimizes $w$. Observe In FIg. 9 that

$$
\theta=(w-c) / 2
$$

In general we do best (mintmum $w$ or $\theta$ ) by choosing the Insertion lens focal length $f$ so that the image $e^{\prime}$ colncides with $w^{\prime}$ and thus $z^{\prime}=z$. That is also true when $e^{\prime}>c$ (not illustrated). Since in this case $e^{\prime}=2 \mathrm{e} / \mathrm{d}_{0}$, we have:

$$
\underline{\mathbf{w}}=2 \mathrm{e} / \mathrm{d}_{\mathrm{o}}+\mathrm{z}_{\mathrm{d}} \text {, }
$$

and using Eq. (30),

$$
\underline{\theta}=\frac{e}{d_{o}}-\frac{c}{2}+\theta_{d} \text { (Case I), }
$$

which also equals the insertion angle, and

$$
f=\frac{z d_{0}}{d_{0}+z} .
$$

However, for 3 limited range of parameters, detailed below, a slightiy smaller $Z^{\prime}$, giving a smaller $e^{\prime}$, w11l yet give a smaller w or $w^{\prime}$. That is, $\frac{F}{i}\left(\mathrm{r} \mathrm{Z}^{\prime} \leq \mathrm{z}\right.$ and $e^{\prime} \leq \mathrm{c}$ we minimize

$$
\begin{aligned}
& w^{\prime}(Z)=e^{\prime}+\left(Z-z^{\prime}\right)\left(c-e^{\prime}\right) / z^{\prime} \\
&=(2 e / F)+\left(Z c F / d_{0}\right)-\left(e Z / d_{0}\right)-c,
\end{aligned}
$$

where

$$
F \equiv\left(d_{o} / f\right)-1 \text { or } f=d_{o} /(1+F)
$$

with respect to $f$. We obtain thereby

$$
\begin{aligned}
& \left.F=\sqrt{2 e d_{o} / z c} \text { (assumes } d_{o}>f\right), \\
& \underline{w}^{\prime}=2 \sqrt{2 z c e / d_{o}}-e z / d_{o}-c,
\end{aligned}
$$

and

$\underline{\theta}=-(\sqrt{2 c / 2}-\sqrt{e / d})^{2}+\theta_{d}$ (Case II),

valid in the range

$$
c /\left(2 e / d_{0}\right) \leq z \leq 2 c /\left(e / d_{0}\right)
$$

Note the $\theta$ of Eq. (37) 15 less than or equal to that of Eq. (31) where Eq. (37) is valid. The insertion angle in this case (Case II) is:

$\underline{\theta}_{\text {Insert }}=-\sqrt{\mathrm{e} / \mathrm{d}_{\mathrm{o}}}\left(\sqrt{2 \mathrm{c} / 2}-\sqrt{\mathrm{e} / \mathrm{d}_{\mathrm{o}}}\right)+\theta_{\mathrm{d}}$.

Thus whenever the conditions of Eq. (38) are met, use Eq. (37) Case II, otherwise use Eq. (31), Case I. In our numerical studies the word focused means choosing f from either Eqs. (35) and (34) or (32) and thereby optimizing $\theta$.

VI. NUMERICAL EXAMPLES

We w11l use a number of typlcal parameters to give the reader some perspective and then vary them to illuatrate tradeoffs. Refer to Table III where we maximize useful absorption with respect to the independent varlables and not to the number of 
TABLE III

SELECEED NIMERICAL RESULTS

\begin{tabular}{|c|c|c|c|c|c|c|c|c|c|c|c|c|c|c|}
\hline $\begin{array}{l}\text { Run } \\
\text { Num- } \\
\text { ber } \\
\end{array}$ & $\begin{array}{l}\text { Beam } \\
\text { Diver- } \\
\text { gence } \\
\text { Half- } \\
\text { Angle } \\
\theta \text { (rad) }\end{array}$ & $\begin{array}{l}\text { Linear } \\
\text { Absorp- } \\
\text { tion, po } \\
\left(\mathrm{cm}^{-1}\right) \\
\end{array}$ & $\begin{array}{l}\text { Width } \\
(\mathrm{cm}) \\
\end{array}$ & $\begin{array}{l}\text { Reflec- } \\
\text { tivity, } \\
\underline{R}\end{array}$ & $\begin{array}{l}\text { Aper- } \\
\text { ture, } \\
\text { a } \\
\text { (cI) } \\
\end{array}$ & $\begin{array}{l}\text { Length } \\
\underline{L}(\mathrm{~cm}) \\
\end{array}$ & $\begin{array}{l}\text { Caut } \\
\text { Ang1e } \\
\text { (rad) } \\
\end{array}$ & $\begin{array}{l}\text { Total } \\
\text { Fraction } \\
\text { of Beam } \\
\text { Usefully } \\
\text { Absorbed }\end{array}$ & $\begin{array}{l}\text { Number } \\
\text { of } \\
\text { Passes }\end{array}$ & $\begin{array}{l}\text { Ab- } \\
\text { sorp- } \\
\text { tion } \\
\text { Ce11 } \\
2 \\
(\%) \\
\end{array}$ & $\begin{array}{l}\text { Maxi- } \\
\text { mium } \\
\text { Ce11 } \\
\text { Ab- } \\
\text { sorp- } \\
\text { tion } \\
(\%) \\
\end{array}$ & $\begin{array}{l}\text { Ab- } \\
\text { sorp- } \\
\text { tion } \\
\text { Ce11 } \\
19 \\
(\%) \\
\end{array}$ & $\begin{array}{l}\text { Beam } \\
\text { Energy } \\
\text { Escaping } \\
(\%) \\
\end{array}$ & Remark \\
\hline \multirow[t]{2}{*}{1} & $1.57(-4)$ & $3.68(-6)$ & 200. & 0.995 & 0.25 & 10. & $9.06(-6)$ & $7.93(-2)$ & 209. & 4.2 & 8.6 & 2.5 & 37.6 & Reference \\
\hline & DL1 & & & & & & & \multicolumn{7}{|c|}{ [6.66(-2) absorbed before beginning leak out at entrance] } \\
\hline 2 & $\begin{array}{l}1.5(-4) \\
\text { focused }\end{array}$ & $3.68(-6)$ & 200. & 0.995 & 0.25 & 10. & $8.9(-6)$ & $8.04(-2)$ & 210. & 4.2 & 8.7 & 2.4 & 37.3 & \\
\hline 3 & $3.14(-4)$ & $3.68(-6)$ & 200. & 0.995 & 0.25 & 10 & $1.46(-5)$ & $6.10(-2)$ & 169. & 4.9 & 8.3 & 2.4 & 52.4 & \\
\hline 4 & $\begin{array}{l}\text { 3. }(-4) \\
\text { focused }\end{array}$ & $3.68(-6)$ & 200. & 0.995 & 0.25 & 10. & $1.42(-5)$ & $6.23(-2)$ & 171. & 4.9 & 8.5 & 2.4 & 51.4 & \\
\hline 5 & $7.84(-4)$ & $3.68(-5)$ & 200. & 0.995 & 0.25 & 10. & $5.14(-5)$ & $\approx 3.6(-2)$ & $\approx 98$. & 8.9 & 10.4 & 1.5 & 71.9 & $\begin{array}{l}\text { Code limit- } \\
\text { ing }\end{array}$ \\
\hline 6 & $\begin{array}{l}7.75(-4) \\
\text { focused }\end{array}$ & $3.68(-6)$ & 200 & 0.995 & 0.25 & 10. & 5. $(-5)$ & $\approx 3.7(-2)$ & $\sim 99$. & 8.7 & 10.4 & 1.6 & 71.1 & $\begin{array}{l}\text { Code limit- } \\
\text { ing }\end{array}$ \\
\hline 7 & $\begin{array}{l}1.57(-4) \\
\text { DL1 }\end{array}$ & $6.11(-7)$ & 200. & 0.995 & 0.25 & 10. & $9.06(-6)$ & $1.38(-2)$ & 209. & 4.1 & 8.6 & 2.5 & 42.2 & \\
\hline 8 & $\begin{array}{l}1.57(-4) \\
\text { DL.1 }\end{array}$ & 1. $(-7)$ & 200. & 0.995 & 0.25 & 10. & $9.06(-6)$ & $0.23(-?)$ & 209. & 4.1 & 8.6 & 2.5 & 43.0 & \\
\hline 9 & $1.57(-4)$ & 1. $(-5)$ & 200. & 0.995 & 0.25 & 10. & $9.06(-6)$ & $19.8(-2)$ & 209. & 4.3 & 8.6 & 2.4 & 30.8 & \\
\hline 10 & $1.57(-4)$ & 1. $(-4)$ & 200. & 0.995 & 0.25 & 10. & $9.06(-6)$ & 79. $(-2)$ & 209. & 8.1 & 8.1 & 1.1 & 1.3 & \\
\hline 11 & $1.57(-4)$ & $3.68(-6)$ & 100. & 0.995 & 0.25 & 10. & $1.28(-5)$ & $4.76(-2)$ & 248 . & 3.7 & 3.7 & 3.5 & 30.5 & \\
\hline 12 & $\begin{array}{l}1.5(-4) \\
\text { focused }\end{array}$ & $3.68(-6)$ & 100 & 0.995 & 0.25 & 10. & $1.26(-5)$ & $4.78(-2)$ & 250. & 3.6 & 8.9 & 3.6 & 30.2 & \\
\hline 13 & $\begin{array}{l}7.84(-5) \\
\text { DL1 }\end{array}$ & $3.68(-6)$ & 700 & 0.995 & 0.5 & 10. & 1. $(-5)$ & $16.3(-2)$ & 105. & 3.5 & 8.4 & 2.8 & 51.9 & \\
\hline 14 & $7.1(-5)$ & $3.68(-6)$ & 700 & 0.995 & 0.5 & 10. & $9.5(-6)$ & $16.8(-2)$ & 107. & 3.4 & 9.8 & 2.8 & 50.5 & \\
\hline 17 & $\begin{array}{l}3.92(-4) \\
\text { DL1 }\end{array}$ & $3.68(-6)$ & 50. & 0.995 & 0.1 & 10. & $7.5(-6)$ & $2.9(-2)$ & 468 & 5.5 & 8.5 & 1.9 & 16.8 & \\
\hline 18 & $\begin{array}{l}3.92(-4) \\
\text { DL1 }\end{array}$ & $3.68(-6)$ & 20. & 0.995 & 0.1 & 10. & $1.12(-5)$ & $1.34(-2)$ & 587 & 5.2 & 8.2 & 1.9 & 7.5 & \\
\hline & & & & & & & (Continu & & & & & & & \\
\hline
\end{tabular}




\begin{tabular}{|c|c|c|c|c|c|c|c|c|c|c|c|c|c|c|}
\hline $\begin{array}{l}\text { Run } \\
\text { Num- } \\
\text { ber } \\
\end{array}$ & $\begin{array}{l}\text { Beam } \\
\text { Diver- } \\
\text { gence } \\
\text { Half- } \\
\text { Angle } \\
\theta \text { (rad) } \\
\end{array}$ & $\begin{array}{l}\text { Linear } \\
\text { Absorp- } \\
\text { tion, } \rho \sigma \\
\left(\mathrm{cm}^{-1}\right) \\
\end{array}$ & $\begin{array}{l}\text { Width } \\
\text { w } \\
(\mathrm{cm}) \\
\end{array}$ & $\begin{array}{l}\text { Reflec- } \\
\text { tivity, } \\
\text { R }\end{array}$ & $\begin{array}{l}\text { ApEr- } \\
\text { ture, } \\
a \\
(\mathrm{~cm}) \\
\end{array}$ & $\begin{array}{l}\text { Length } \\
\underline{L} \text { (c⿴囗十) }\end{array}$ & $\begin{array}{l}\text { Cant } \\
\text { Angle } \\
\text { (rad) } \\
\end{array}$ & $\begin{array}{l}\text { Total } \\
\text { Fraction } \\
\text { of Beam } \\
\text { Usefully } \\
\text { Absorbed }\end{array}$ & $\begin{array}{l}\text { Number } \\
\text { of } \\
\text { Passes }\end{array}$ & $\begin{array}{l}\text { Ab- } \\
\text { sorp- } \\
\text { tion } \\
\text { Cell } \\
2 \\
(\%) \\
\end{array}$ & $\begin{array}{l}\text { Maxi- } \\
\text { mum } \\
\text { Cell } \\
\mathrm{Ab}- \\
\text { sorp- } \\
\text { tion } \\
(\%) \\
\end{array}$ & $\begin{array}{l}\text { Ab- } \\
\text { sorp- } \\
\text { tion } \\
\text { Cell } \\
19 \\
(\%) \\
\end{array}$ & $\begin{array}{l}\text { Beam } \\
\text { Energy } \\
\text { Escaping } \\
(\%) \\
\end{array}$ & Remark \\
\hline \multirow[t]{2}{*}{19} & $1.57(-4)$ & $3.68(-6)$ & 200 & 0.995 & 0.25 & 20. & $4.2(-6)$ & $10.9(-2)$ & 437. & 5. & 8.1 & 2.3 & 14.9 & \\
\hline & DLl & & & & & & & & & & & & & \\
\hline \multirow[t]{2}{*}{21} & $1.57(-5)$ & $3.68(-6)$ & 200. & 0.995 & 0.25 & 5. & $1.88(-5)$ & $4.78(-2)$ & 101. & 3. & 8.7 & 2.8 & 62.7 & \\
\hline & DLl & & & & & & & & & & & & & \\
\hline 22 & $1.57(-4)$ & $3.68(-6)$ & 200. & 0.995 & 0.25 & 2.5 & 4. $(-5)$ & $2.48(-2)$ & 49. & .3 & 8.7 & 3.4 & 80.7 & \\
\hline 24 & $1.57(-4)$ & $3.68(-6)$ & 200 & 0.9 & 0.25 & 10. & $9.1(-6)$ & $.73(-2)$ & 209. & 25.7 & 25.7 & .005 & $<10^{-4}$ & \\
\hline 25 & $1.57(-4)$ & $3.68(-6)$ & 200. & 0.96 & 0.25 & 10. & $9.1(-6)$ & $1.8(-2)$ & 209. & 12.3 & 12.3 & .4 & 0.13 & \\
\hline 26 & $1.57(-4)$ & $3.68(-6)$ & 200. & 0.98 & 0.25 & 10. & $9.1(-6)$ & $3.43(-2)$ & 209. & 7.1 & 7.8 & 1.3 & 3.24 & \\
\hline 27 & $1.57(-4)$ & $3.68(-6)$ & 200. & 0.99 & 0.25 & 10. & $9.1(-6)$ & $5.71(-2)$ & 209. & 4.9 & 8.5 & 2.1 & 16.6 & \\
\hline 28 & $1.57(-4)$ & $3.68(-6)$ & 200. & 0.998 & 0.25 & 10. & $9.1(-6)$ & $9.94(-2)$ & 209. & 3.9 & 8.6 & 2.6 & 63.0 & \\
\hline 29 & $1.57(-4)$ & $3.68(-6)$ & 200. & 0.999 & 0.25 & 10. & $9.1(-6)$ & $10.8(-2)$ & 209. & 3.9 & 8.5 & 2.7 & 74.6 & \\
\hline \multirow[t]{2}{*}{30} & $1.57(-4)$ & $3.68(-6)$ & 200. & 0.9999 & 0.25 & 10. & $9.1(-6)$ & $11.6(-2)$ & 209. & 3.8 & 8.5 & 2.7 & 86.8 & \\
\hline & & & & & & & \multicolumn{7}{|c|}{ [10.8(-2) absorbed before beginning leak out at entrance] } & \\
\hline 31 & $\begin{array}{l}3.92(-5) \\
\text { DL1 }\end{array}$ & $3.68(-6)$ & 200. & 0.995 & 1.0 & 10. & $7.8(-5)$ & $4.02(-2)$ & 68. & 2.9 & 12.8 & 12.8 & 69.4 & $\begin{array}{l}\text { Cell } 3 \text { and } \\
18\end{array}$ \\
\hline 32 & $\begin{array}{l}7.84(-5) \\
\text { DL1 }\end{array}$ & $3.68(-6)$ & 200. & 0.995 & 0.5 & 10. & $2.1(-5)$ & $6.55(-2)$ & 134. & 3.3 & 10.5 & 5.8 & 48.9 & $\begin{array}{l}\text { Cell } 3 \text { and } \\
18\end{array}$ \\
\hline 34 & $\begin{array}{l}2.18(-4) \\
\text { DL.1 }\end{array}$ & $3.68(-6)$ & 200. & 0.995 & 0.18 & 10. & $7.6(-6)$ & $7.72(-2)$ & 232 . & 5.2 & 8.5 & 2.1 & 39.8 & \\
\hline 33 & $\begin{array}{l}3.92(-4) \\
\text { DLL1 }\end{array}$ & $3.68(-6)$ & 200 & 0.995 & 0.1 & 10. & $1.08(-5)$ & 25.8(-2) & 192. & 11.6 & 11.6 & 1.3 & 55. & Code limited \\
\hline 35 & 0 & $3.68(-6)$ & 200. & 0.995 & 0.6 & 10. & 0 & $3.9(-2)$ & 63. & 5.2 & 5.2 & 5.1 & 69.7 & $\begin{array}{l}\text { Parallel } \\
\text { mirrors }\end{array}$ \\
\hline \multirow[t]{2}{*}{36} & $3.92(-4)$ & $3.68(-6)$ & 20. & 0.995 & 0.1 & 3.5 & $3.2(-5)$ & $8.64(-3)$ & 206. & 3.4 & 8.7 & 3.2 & 40.4 & \\
\hline & DL1 & & & & & & & & & & & & & \\
\hline 37 & $\begin{array}{l}3.92(-4) \\
\text { DL1 }\end{array}$ & $6.11(-7)$ & 20. & 0.995 & 0.1 & 3.5 & $3.2(-5)$ & $1.44(-3)$ & 206. & 3.4 & 8.7 & 3.2 & 40.8 & \\
\hline
\end{tabular}


TABLE III (continued)

\begin{tabular}{|c|c|c|c|c|c|c|c|c|c|c|c|c|c|c|}
\hline $\begin{array}{l}\text { Run } \\
\text { Num- } \\
\text { ber } \\
\end{array}$ & $\begin{array}{l}\text { Beam } \\
\text { Diver- } \\
\text { gerce } \\
\text { Half- } \\
\text { Angle } \\
\theta \text { (rad) } \\
\end{array}$ & $\begin{array}{l}\text { Linear } \\
\text { Absorp- } \\
\text { tion, po } \\
\left(\mathrm{cm}^{-1)}\right. \\
\end{array}$ & $\begin{array}{l}\text { Width } \\
\text { w } \\
\text { (cm) } \\
\end{array}$ & $\begin{array}{l}\text { Reflec- } \\
\text { tivity } \\
\text { R } \\
\end{array}$ & $\begin{array}{l}\text { Aper- } \\
\text { ture } \\
\text { a } \\
(\mathrm{cm}) \\
\end{array}$ & $\begin{array}{l}\text { Length } \\
\underline{L}(\mathrm{~cm})\end{array}$ & $\begin{array}{l}\text { Cant } \\
\text { Angle } \\
\text { (rad) } \\
\end{array}$ & $\begin{array}{l}\text { Total } \\
\text { Fraction } \\
\text { of Beam } \\
\text { Usefully } \\
\text { Absorbed }\end{array}$ & $\begin{array}{l}\text { Number } \\
\text { of } \\
\text { Passes }\end{array}$ & $\begin{array}{l}\text { Ab- } \\
\text { sorp- } \\
\text { tion } \\
\text { Cell } \\
2 \\
(\%) \\
\end{array}$ & $\begin{array}{l}\text { Maxi- } \\
\text { mum } \\
\text { Cel1 } \\
\text { Ab- } \\
\text { sorp- } \\
\text { tion } \\
(\%) \\
\end{array}$ & $\begin{array}{l}\text { Ab- } \\
\text { sorp- } \\
\text { tion } \\
\text { Cel1 } \\
19 \\
(\%) \\
\end{array}$ & $\begin{array}{l}\text { Beam } \\
\text { Energy } \\
\text { Escaping } \\
(\%) \\
\end{array}$ & Remark \\
\hline \multirow[t]{2}{*}{ 38B } & $7.84(-4)$ & $6.11(-7)$ & 20. & 0.995 & 0.05 & 3.5 & $2.35(-5)$ & $21.4(-3)$ & 263. & 5.7 & 8.9 & 2.0 & 42.6 & \\
\hline & DL1 & & & & & & & & & & & & & \\
\hline \multirow[t]{2}{*}{39} & $7.84(-5)$ & $6.11(-7)$ & 20. & 0.995 & 0.5 & 3.5 & $5.8(-4)$ & $4.83(-4)$ & 46. & 3.1 & 12.6 & 9.8 & 80.2 & Cell 4 \\
\hline & DL1 & & & & & & & & & & & & & \\
\hline \multirow[t]{2}{*}{40} & $-1.82(-4)$ & $6.11(-7)$ & 20. & 0.995 & 0.5 & 3.5 & $5.4(-4)$ & $5.12(-4)$ & 48. & 3.1 & 15.9 & 13.9 & 79.0 & Cell 4 \\
\hline & focused & & & & & & & & & & & & & \\
\hline 41 & $1.3(-3)$ & $6.11(-7)$ & 20. & 0.995 & 0.5 & 3.5 & $8.3(-4)$ & $3.77(-4)$ & $=9$. & 2.9 & 9.2 & 1.4 & 84.6 & Ce11 4 \\
\hline \multirow[t]{2}{*}{42} & $9.9(-4)$ & $6.11(-7)$ & 20. & 0.995 & 0.5 & 3.5 & $7.7(-4)$ & $4.01(-4)$ & 40. & 4.3 & 9.9 & 4.8 & 83.6 & Ce11 S \\
\hline & focused & & & & & & & & & & & & & \\
\hline \multirow[t]{2}{*}{43} & $3.92(-4)$ & $3.68(-6)$ & 20. & 0.995 & 0.1 & 5.5 & $2.0(-5)$ & $1.10(-2)$ & 323. & 4.1 & 8.7 & 2.7 & 24.0 & \\
\hline & DLl & & & & & & & & & & & & & \\
\hline 44 & $1.3(-3)$ & $6.11(-7)$ & 20. & 0.995 & 0.5 & 5.5 & $4.9(-4)$ & $6.14(-4)$ & 65. & 3.9 & 9.3 & 4.2 & 74.8 & Cell 4 \\
\hline \multirow[t]{2}{*}{45} & $1.1(-3)$ & $6.11(-7)$ & 20. & 0.995 & 0.5 & 5.5 & $4.6(-4)$ & $6.35(-4)$ & 66. & 3.8 & 9.5 & 4.6 & 74.0 & Cel1 4 \\
\hline & focused & & & & & & & & & & & & & \\
\hline \multirow[t]{2}{*}{46} & $3.7(-4)$ & 1. $(-5)$ & 20. & 0.9999 & 0.1 & 5.5 & $1.96(-5)$ & $5.58(-2)$ & 333. & 3.4 & 9.0 & 3.6 & 91.6 & \\
\hline & focused & & & & & & & & & & & & & \\
\hline 48 & 3. $(-3)$ & 3. $(-7)$ & 20. & 0.9 & 0.5 & 3.5 & $1.28(-3)$ & $5.52(-5)$ & 31. & 3.1 & 8.9 & 2.0 & 8.0 & Cell 3 \\
\hline
\end{tabular}


passes. Because of leakout of beam edges these quantities do not maxtmize together. Because our chambers are designed to optimize absorption for low values of the product of absorber molecular density $\rho$, and cross-section $\sigma$, the product $\rho \sigma$ in column 3 of Table III is chosen to be a low number. Column 2 gives the far-field beam divergence; DLl means that the half-angle is the first minimum in the onedimensional Frauenhofer pattern of an intially uniform beam, whereas focused means the half-angle given is that calculated from the theory of Sec. IV. Refer to Fig. 1 for the meaning of the dimensions $w$ and $L$. All losses, save useful absorption, are lumped into the reflectivity loss, $1-R$, where $R$ is given in Column 5 . The aperture a of column 6 is the beam entrance width along the chamber dimension L. Column 8 gives the angle between the two canted mirrors. Column 9 is the chlef result and is the fraction of beam usefully absorbed or reacted in the chamber for negligible absorber depletion. Column 10 gives the number of passes of the beam before $1 t$ wholly exits from the chamber. Edges of the beam do leak out before this pass number is reached. We could nake the number of passes higher but thereby lose useful absorption. Columns 11-13 indicate the uniformity of fllumination in the cavity. The code divides up the $L \times h$ face (Fig. 1) of the cavity into 20 cells along the dimension $L$ and sums the light intensity in each cell, printing the result as a percent of the total integrated intensity on the whole face or mirror. We give the result for the second cell inward, namely cell 2 in Column 11 near the entrance and cell 19 in column 13 near the narrow part of the canted mirrors. If the aperture Is appreciable compared with the length $L$, the absorption of the $2 \mathrm{~d}$ cell is abncrmally low (see Fig. 3) so that for these cases (Column 11) we take the outermost cell at which the beam begins to be reflected on itself in place of cell 2 and note the cell used in the last column, Remark. Column 12 1ists the maximum integrated cell absorption in percent, which usually occurs close to the center of the chamber except when the losses per pass are hlgh as in runs 24 and 25 for example. The maximum cell mi:ror Intensity may be calculated by the formula:

$$
\vec{I}=\frac{E_{o}}{w \rho O} \frac{\bar{A}_{c}}{100} \frac{20 A_{t}}{h L},
$$

good for $w \rho \sigma \ll 1$, where $E_{o}$ is the initial beam energy, $\bar{A}_{c}$ is the maximum percent cell absorption of colum 12, $A_{t}$ is the total useful absorption of Column 9, and $T=(1-w p \sigma)$ is the transmission through the cavity in the dimension $w$. Thus the maximum cell intensity in Case 1 of Table III is $18.5 \mathrm{~J} / \mathrm{cm}^{2}$ per joule of beam power (the average mirror loading is $10.8 \mathrm{~J} / \mathrm{cm}^{2}$ per pulse per foule). Note that maximum cell incensity is not the highest possible intensity, one must guard agalnst highintensity diffractive spikes in any optical system. ${ }^{5}$ The 14th column gives the beam energy escaping the chamber, mostly back out the entrance aperture. For high reflectivity, a weakly absorbing medium, and a small chamber, the escape loss is large. One may have to spatially or temporally isolate the laser, or best of all, use time-dependent reflecting devices to return the beam for multiple travels in the chamber. In the last column the remark "code 1imiting" iefers to the fact that our code will not permit simultaneous beam loss at both ends of the cavity in a given pass. The values so given are satisfactory but not as accurate as they might otherwise be. This quirk prevents the study of very highly divergent beams with our code as presently written.

Run 1 is our reference; we will vary parameters about the values of this run. The chamber size is $200 \times 10 \times 1 \mathrm{~cm}^{3}$ with parasitic losses per pass of $0.5 \%$ and a useful medium linear absorption $(p \sigma)$ of $3.68(-6) \mathrm{cm}^{-1}$. The aperture is $0.25 \mathrm{~cm}$ wide and a diffraction-1imited $0.25 \times 1 \mathrm{~cm}^{2}$ beam with a horizontal divergence of $1.57(-4)$ radians half-angle issues into the cavity. For these parameters our total beam fractional useful absorption is 0.0793 in 209 passes before the beam is wholly out of the chamber. The average uniformity of fllumination is good, varying by about a factor of 2 over the chamber. Thirty-seven and six-tenths percent of the original beam energy escapeg the chamber. Optimal focusing can improve mateers only slightly for these parameters to 0.0804 fractional absorption as run 2 shows. The sequence of runs 1,3 , and 5 shows the 
effect of loss of beam quality (divergence halfangle) on useful absorption, and runs 2, 4, and 6 give the same when optimally focuseil. Bean quality is an important parameter for these cavities, but cavity performance diminishes less than proportional to beam divergence. For these parameters, focusing is of negligible help, but may be significant for other parameters as shown in Table III.

The sequence of runs $8,7,1,9$, and 10 shows the effect of increasing the absorption $\rho \sigma$ of che medium; it is obvious that high-medium absorptivity is desired.

The run sequence $18,17,11,1$, and 13 shows the gains to be made by using wider (w) chambers, with runs 12 and 14 giving a check on the help that opt fmum focusing can give. Again the gains are not quite proportional to the increase in $w$ with even less gain going to $700 \mathrm{~cm}$.

The run sequence $22,21,1$, and 19 shows the effect of longer ( $L$ ) chambers. Here too the absorption gain is not quite proportional to the Increase in 1. with least gain for the longest.

The sequence of runs $24,25,26,27,1,28,29$, and 30 shows the advantages of higher mirror reflectivity or lower parasitic loss. Note that low loss to the mirrors means high escape to the entrance, as it should. Note also that unless one uses a size chamber or a type design that allows very many passes before leakout, one gains only a little beyond reflectivities of about 0.998 in this size chamber $\left(200 \times 10 \mathrm{~cm}^{2}\right)$. The gatns at f1rst are roughly proportional to $(1-R)^{-1}$ but taper of $f$ to less than that at high $R$. An Infinitely trapped beam has useful absorption proportional to wpo/(1-RT) which for woo 1 is proportional to $(1-R)^{-1}$. These remarks represent the fact that high refleccivities are utilized to the fullest only ln highly trapped beam chambers.

The run sequerice $31,32,1,34,33$ shows the ef fect of changing the aperture $a$. Upon narrowing the aperture, one at first galis usef(u) absorption because the beam can be returned at smaller angles and so pack more passes into the chamber, but the higher diffractive angles at the lower apertures eventually cause such beam spreading as to allow the escape of light from the cavily ends.

Run 35 shows what can be done in a $200 \times 10$ $\times 1 . m^{3}$ chamber with parallel airrors (rype af of
Sec. II). The beam is taken to have negligible divergence or convergence over its path. In point of fact a cohrient Gaussian beam with a walst of $0.6 \mathrm{~cm}$ will spread to $0.8 \mathrm{~cm}$ on either edge of 63 passes $\times 200-\mathrm{cm}$ width. The fractional useful absorption, $\mathrm{E}_{\mathrm{O}} \mathrm{E}_{0}$, of a beam making n passes wholly within a reaction chamber is:

$$
E / E_{0}=w p o\left(1-R^{n} T^{n}\right) /(1-R T)
$$

This formula or alternatively our machine calculation for $\theta=0$ gives the useful absorption of Line 35 in Table III. Run 35 shows a very respectable absorption of $3.9 \%$ with a nearly perfect average unfform distribution. We do not at this time study diffraction spikes in the heam itself which must be allowed for in practical designs. 5

In runs 36 to 48 we study in greater detall the properties of a small cavity, one with $w=20 \mathrm{~cm}$ and $L=3.5$ or $5.5 \mathrm{~cm}$. Runs 36 nnd 37 show the effect of lowering $\rho \sigma$ by a factor of 5.57 for $L=3.5 \mathrm{~cm}$. Then at the lower medium absorption the best absorption occurs for apertures of about $0.1 \mathrm{~cm}$ as runs 37 and $38 \mathrm{~b}$ show. If we must use an aperture of $0.5 \mathrm{~cm}$ (not necessary, one can use beam compression - see IVA), run 39 shows what can be achieved. Here focusing gives some improvement as run 40 shows. A highly divergent $0.5-\mathrm{cm}$ beam of run 41 can be focused to give the result of run 42 . Runs 43 to 45 repeat these calculations for the longer cavity, $L=5.5 \mathrm{~cm}$.

Last, runs 46 and 48 give the extremes that mjght be expected, taking for run 46 the most favorable parameters to be expected near the ones ve have chosen, and for run 48 the least favorable, obtaining thereby relative absorptions in a $20-\mathrm{cm}$ chamber ranging from $5.6 \%$ to $0.0055 \%$. Of course, widely different parameters will give yet wider results, thus a $\%$ of $10 \mathrm{~cm}^{-1}$ gives $100 \%$ absorption in $20 \mathrm{~cm}$ (one pass).

\section{CHAMBER ENERGETICS - MIRROR INTENSITIES}

If the absorbing molecular density is 2 , the lighe energy per unit volume needed to react or be atisorbed on ald the nolecules is then

$$
\sin / c_{q}
$$

where h. Is the guantum energy and iq the quantum 
effictency of the reaction or absorption desired. During the pulse length, $\Delta t$, a summed beam of intensity $I$ dumps an energy denslty of

$$
\frac{d I}{d z} \Delta t=I \rho \sigma \Delta t
$$

Into the medium, so that the summed energy density per pulse for complete reaction is lequating (42) and (43)]:

$$
\mathrm{I} \Delta \mathrm{t}=\frac{\mathrm{hc}}{\lambda \sigma \varepsilon_{\mathrm{q}}} \text {, }
$$

where $\lambda$ is the wavelength. This energy density is that needed to react the molecules in the chamber; it does not depend on the density of molecules, the chamber width, nor any other macroscopic varlable save only that the absorption be weak else one must compensate for the intensity diminution of the beam across the chamber. Weak absorption means a low cross-section $\sigma$, which in turn requires high-intensity beams which may exceed mirror or other tolerances of the reaction chamber. Note that the energy density in Eq. (44) is the summed energy density so that if the mirror tolerance is based on power and not energy (1.e., say avalanche 1 imiting versus impurity heat limiting), the high intensity of Eq. (44) may be safely achieved by multiple passes of weaker intensity beams.

For example let $\uparrow \downarrow 0.4 \mathrm{um}, \sigma=1.8 \times 10^{-20}$ $\mathrm{cm}^{2}, \varepsilon_{q}=1$, then $1 \Delta t=28,2 \mathrm{~J} / \mathrm{cm}^{2}$. For $\Delta t$ shorter than about 1 us this esergy densicy greatly exceeds the tolerance of most mirrors.

Both the canted, Type $\underline{b}$, and the parallel, Type a, reaction chambers multiply the bear intensity at a point by overlapping the beam. The latter, Type a. in the limit of low total loss increases the beam Intensity by a factor of 4 uniformly throughout the chamber save at the ends. The canted mirror chamber can achieve higher beam intensity multiplicatton (in excess of $6 x$ ) but at the expense of uniformity. The actual multiplications in Table II are somewhat less than the above because of the actenuation of the returning beim. For example in place of $\times 4$ in the uniform case, Run 35 achleves x3.3 for the chosen parameters, and the reference canted case, run 1 , achieves an actual maximum multiplication of $\times 4.6$ versus a true effective beam overlap of $6 x$ or more. Conversely, such beam mult1plication may permit higher absorptions without exceeding mirror tolerance if the damage mechanism is power dependent (such as electron avalanche).

VIII. SUMMARY

Plane or cylindrically concave mirrors provide in either canted or parallel configurations a simple, adaptable (to changing beam parameters and absorption parameters) reaction cavity giving high relative absorption together with a high or nearly perfect uniformity of illumination. Useful absorption or reaction increases approximately linearly with absorber density, cross section, chamber width, or chamber length, and approximately inversely as the beam divergence and as the parasitic losses $(1-R)$. In every case above, the increase is somewhat less than Ifnear, tapering to appreclably less than linear as the given parameter is carried to an extreme - a law of diminishing returns. The use of beam compressing (expansion) by telescope permits adjusting the aperture to optimum. Insertion focusing can Improve performance only slightly when long beatn paths in the chamber are possible, but appreciably for short paths.

\section{ACKNOWLEDGEMENTS}

It is a pleasure to acknowledge conversations with, and comments from, the following Los Alamos Sclentiftc Laboratory colleagues: L. A. Booth, R. S, Cooper, J. M. Will1ams, C. M. Gillespie, F. T. Finch, J. R. Bobbitt, E. Heck, P. Robinson, T. Cotter, H. Flicker, T. G. Frank, and F, Harlow.

\section{REFERENCES}

1. M. Born and E. Wolf, Principles of Optics (Pergammon Press, New York, 1959), p. 625.

2. D. E. Gray, Editor, American Institute of Physics Handbook, 2nd Edicion (McGraw-Hill, New York, 1963).

3. H. Kogelnik and T. LA, "Laser Beams and Resonators," Appl. Optics 5, 1550 (1966).

4. A. C. Fox and T. Li las quoted in A. E. Siegman, An Introduction to Lasers and Masers] (McGrawH111, New York, 1971), p. 335.

5. James Terrel1, Los Alamos Scientific Laboratory, private communication, 1974. 
6. Bergen Suydam, Los Alamos Sclentific Laboratory, private communication, 1974.
7. For example see the "Third Conference on HighPower Infrared Laser Window Materials," Alr Forc Cambridge Research Laboratory report (to be published).

APPENDIX

HIGH ABSORPTION OF LIGHT, BLEACHING

J. J. Devaney

Absorption formulae for light are given for the case that appreclable depletion of the absorber is possible.

Suppose we have an absorber shose absorption cross section 150 , whose absorption molecular density is $\rho$, upon which we shine light of intensity $I_{0}$, of photon energy hv, for a time from $t=0$ to $t=t$, In the $x-d i r e c t i o n$, normally incident on a semi-infinite slab (one-dimensional beam geometry). Unless density fluctuations exist, the effect of scattering is only to change the velocity of Ilght from the vacuum value of $c$ to $c / n$, where $n$ is the Index of refraction of the absorber. For the calculation of absorption itself the velocity of 1 ight Is not pertinent, save that it be sufficlently fast compared to other parameters, so we need take no further notice of scattering. The effect of density fluctuations, an interesting subject, must be reserved for a future study.

If we have an initial absorbing molecular density $t_{0}$ that is not depleted, the familiar exponent lal beam absorption obtains:

$$
I=I_{0} e^{-\rho_{0} \sigma x} \text { (no depletion for ali } t \text { ). (A-I) }
$$

In the other $11 \mathrm{~m} 1 \mathrm{t}$, when absorption and consequent depletion are large, one can approximate the light wave envelope by a sugure wave eacing inco the material and obtain the velocity of such a bleaching wave by balancing ersergy losses. The energy lost by the beam per unit area during a $t \pm m e, d t$, is $\Delta$ idt, which is taken up by Apdx molecules per unit

$$
\Delta \mathrm{Idt}=\mathrm{h} v \Delta \rho \mathrm{dx}
$$
area so that:

$$
\frac{\partial I}{\partial x}=h v \frac{\partial p}{\partial t},
$$

where one molecule is removed for one photon, hw, absorbed.

For a square wave, $\Delta I$ is precisely $I_{0}$, and $\Delta p$ is precisely ${ }^{\circ} \circ$ Equation $(A-2 a)$ then gives the velo:fty, $v$, with which the light eats into the matertal, bleaching $1 t$ :

$$
v=I_{0} /\left(h \cup \rho_{0}\right)
$$

(large depletion and large $\rho_{0} \mathfrak{J}$ ).

Thus for distances less than $x_{v}=v t$, we have $\rho=0$ and $I=l_{0}$ and for greater alstances, $\rho=\rho_{0}$ and $I=0$, See Fig. A-1.

For the general case our intensity differential equation becomes nonlinear:

$$
d I=-I(x, t) ;(x, t) d d x \text {, }
$$

with the boundary and initial conditions: For $t=0$,

$$
\begin{gathered}
N=I_{0} \\
I=I_{0} e^{-\rho_{0} \sigma x}\left(\frac{c}{n} \operatorname{large}\right) ;
\end{gathered}
$$

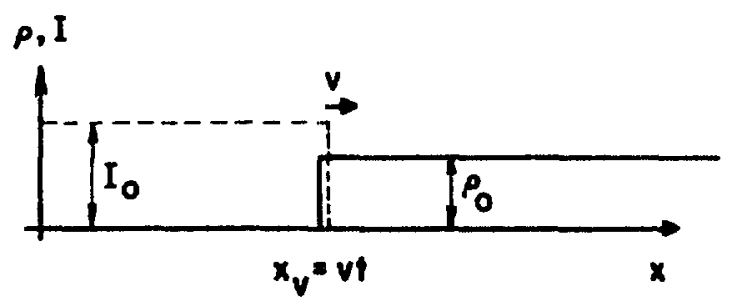

or 
For $x=0$,

$$
\begin{gathered}
\rho=\rho_{0} e^{-\rho_{0} \sigma v t}, \\
I=I_{0} ;
\end{gathered}
$$

$(A-6 a)$

$(A-6 b)$

For $t=\infty, x \neq \infty$,

$$
\begin{aligned}
& \rho=0, \\
& I=I_{0} ;
\end{aligned}
$$

For $t \neq \infty, x=\infty$,

$$
\begin{aligned}
& \rho=\rho_{0} \\
& I=0 .
\end{aligned}
$$

Using Eq. (A-2b) we obtain the solution

$$
1=1_{0}\left[1-\left(1-e^{D_{0} \sigma x}\right) e^{-p_{0} \sigma v t}\right]^{-1}
$$

with $v=I_{n} / h \cup \rho_{0}$, which satisfles Eqs. $(A-S b),(A-$ $6 b)$. $(A-7 b),(A-B b)$, and

$$
0=n_{0}\left(I / L_{0}\right) e^{\mu j(x-v t)} \text {. }
$$

$\rho=\rho_{0} e^{\rho_{0} \sigma(x-v t)}\left[1-\left(1-e^{\rho_{0} J x}\right) e^{-\rho_{0} \sigma v t}\right]^{-1}, \quad(A-10 b)$ which satisfies Eqs. $(A-5 a),(A-6 a),(A-7 a)$, and (A8a).

Equations (A-9) and $(A-10)$ are our general results.

The half-light Intensicy, $I_{0} / 2$, and the mean depletion position, $\rho_{0} / 2$, become identical at large $\rho_{0} \sigma_{X}$ and travel at the speed $v$ of Eq. (A-3). For large $\rho_{o} \sigma x, I$ and $i$ are symmetric about such halfpoint and complementary to each other, see Fig. A-2.

Moreover, as $P_{0}$ increases, the waves steepen, approaching square waves, Fig. A-1, and Eq. (A-3) in the limit. The other limit, Eg. $(\Lambda-1)$ is achieved for $\rho_{o}$ ovt $\rightarrow 0$, which is to say when no time exists that will deplete $\rho_{o}$, the usual (i.e., nondepletion) assumption.

Equation $(A-10)$ not only gives the molecular denstey as a function of $t$ for light of intensity. $I_{a}$, beginning at $t=0$ and lasting indefinitely, but Eq. (A-10b) also gives the resulting density, $D$, from a square pulse of intensity, $I_{0}$, of length $t$, incident on a medium of intetal molecular denstey, $\rho_{\mathrm{c}}$, and cross section, $J$.

Figure A-3 presents a numerical example for an absorber of inteial molecular dengity $\rho_{0}=2.75 \times 10^{14}$ $\mathrm{cm}^{-1}$ and 1 ight intensity $\mathrm{l}_{0}=1.27 \times 10^{10} \mathrm{erg} / \mathrm{cm}^{2}-\mathrm{s}$ $=0.00127 \mathrm{~J} \mathrm{~cm}^{2}-$ us. All waves exhiblted regardlass of cross section, 1, have the same half-intensity veloclty, $v=2.007 \times 10^{8} \mathrm{~cm} / \mathrm{s}$. 


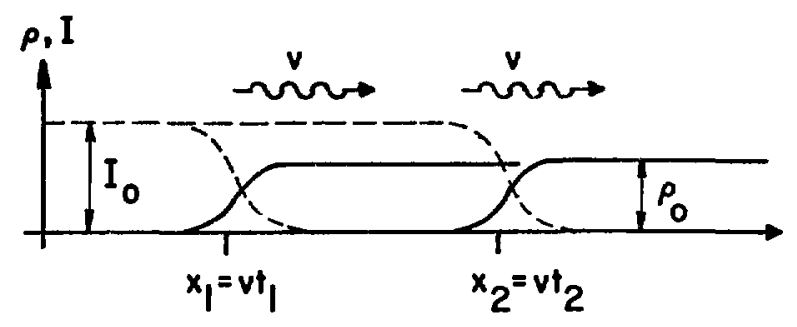

Fig. A-2. General depletion waves. (Left hand: waves at $t_{1}<t_{2}$, right hand: waves at $t_{2}$.)

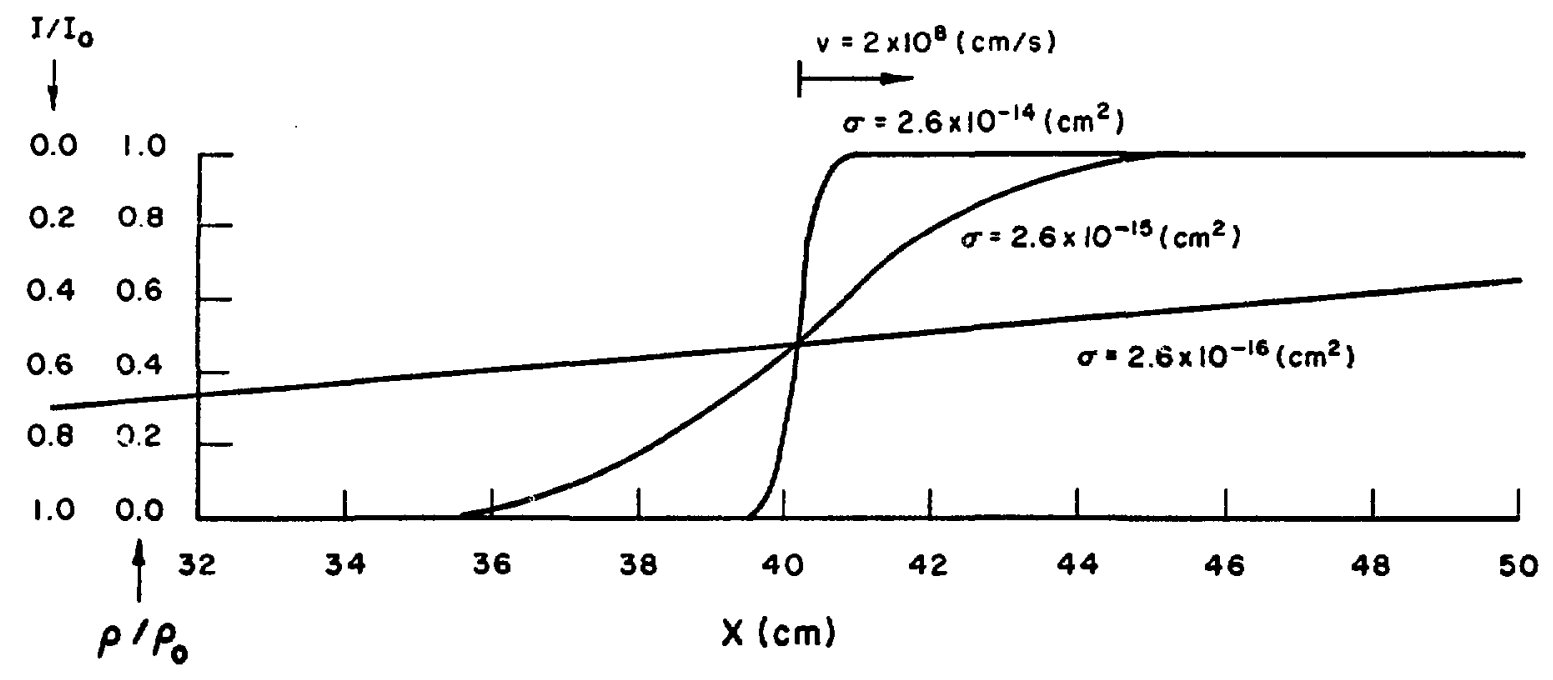

Fis. A-3. Bleaching of absorber illustrited at $t=0.2$ ils. 